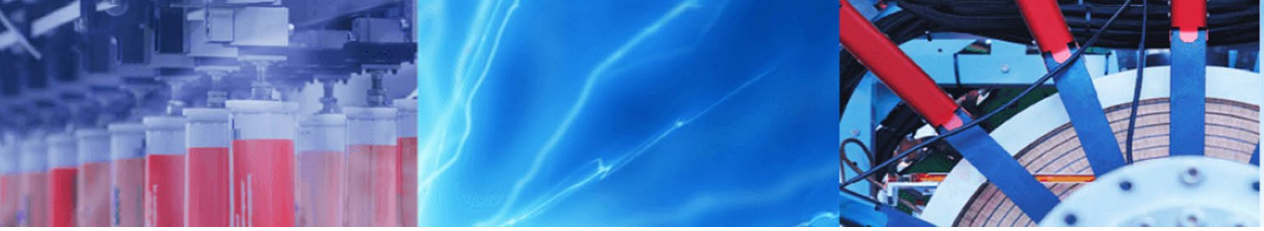

Research Article

\title{
Effect of fly ash on carbon mineralization of biochar and organic manures added to mine spoil
}

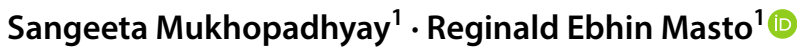

(c) Springer Nature Switzerland AG 2019

\begin{abstract}
Mine spoil is deprived of organic carbon. Reclamation and re-vegetation of mine spoil initiate photosynthetic carbon fixation and add soil organic matter. Fly ash (FA) generated from coal-fired power stations can be used for reclamation of mine spoil. Our research was aimed to assess the effect on FA on carbon mineralization of organic manures and biochar added to mine spoil. Incubation experiments were conducted to assess the carbon mineralization of farmyard manure (FYM), chicken litter (CL), plant litter (PL), and biochar (BC) added to mine spoil in the presence and absence of FA. After 1 year of incubation, the cumulative $\mathrm{CO}_{2}$ emission was lower for the $\mathrm{FA}$-added mine spoil and it was higher for PL (4.42 vs. $5.09 \mathrm{~g} \mathrm{CO}_{2}-\mathrm{C} / \mathrm{kg}$ soil, with and without $\mathrm{FA}$, respectively) and $\mathrm{CL}$ ( $3.75 \mathrm{vs} .4 .07 \mathrm{~g} \mathrm{CO}_{2}-\mathrm{C} / \mathrm{kg}$ soil) followed by FYM (1.86 vs. 1.97 ) and $\mathrm{BC}\left(0.67 \mathrm{vs} .0 .54 \mathrm{~g} \mathrm{CO}_{2}-\mathrm{C} / \mathrm{kg}\right.$ soil). The labile $\mathrm{C}$ pool was significantly lower for $\mathrm{FA}$-added mine spoil, whereas the stable carbon pool was higher in FA-added soils: $\mathrm{FYM} \mathrm{(1.4} \mathrm{vs.} 0.6 \mathrm{~g} \mathrm{CO}_{2}-\mathrm{C} / \mathrm{kg}$ soil) and $\mathrm{CL}\left(2.20 \mathrm{vs} .3 .17 \mathrm{~g} \mathrm{CO}_{2}-\mathrm{C} / \mathrm{kg}\right.$ soil). Substrate-induced respiration, microbial biomass carbon (MBC), and dissolved organic carbon (DOC) were significantly higher under PL, $\mathrm{CL}$, and FYM. FA increased $\mathrm{MBC}$, but decreased DOC. Overall, FA decreased $\mathrm{CO}_{2}$ emission from mine spoil probably due to the interaction of organic matter with the surfaces on FA and the resultant physical protection against microbial decomposition.
\end{abstract}

Keywords Fly ash $\cdot$ Mine spoil $\cdot$ Biochar $\cdot$ Manure $\cdot$ Carbon pool $\cdot$ Carbon mineralization

\section{Introduction}

Worldwide coal is the second largest energy source next to petroleum and other liquid fuels [19]. Large amount of terrestrial carbon are lost due to mining of coal and its subsequent firing in power plants [29, 32]. Reclamation of coal mine degraded lands provides an opportunity for $C$ sequestration [1-3, 31]. Mine spoil is generally very coarse and many times difficult to establish vegetation. Spontaneous vegetation of abandoned mine spoil is very slow. The vegetation process could be accelerated by adopting different reclamation strategies. Land shaping, addition of top soil, organic materials, plant nutrients, insecticides, and irrigation water are some of the major inputs required for mine spoil reclamation. Land shaping is mainly focused on stabilizing the slopes and establishing drainage channels to prevent erosion. As the mine spoil is coarse with difficult physical condition for plant establishment, addition of top soil, FA, organic wastes like processed sewage sludge, etc., would be helpful. Seeding or planting healthy sapling on the treated mine spoil is normally practiced.

Soil $C$ has been shown to increase rapidly by mine soil reclamation because initially mine spoils lack soil organic carbon [11, 30,45]. Soil carbon pools are dynamic and subject to loss, especially the soil carbon is mineralized back to atmosphere as $\mathrm{CO}_{2}$. Only a small portion of the carbon added to the soil is retained as long live stable carbon in soil; rest is released back to atmosphere. Management strategies should concentrate on increasing the size of stable carbon pools [30].Coal combustion in

Reginald Ebhin Masto, mastocfri@yahoo.com | 1 Industrial Biotechnology and Waste Utilization Research Group, CSIR-Central Institute of Mining and Fuel Research, Digwadih Campus, PO: FRI, Dhanbad, Jharkhand 828108, India.

SN Applied Sciences (2019) 1:1119| https://doi.org/10.1007/s42452-019-1140-x

Received: 31 May 2019 / Accepted: 20 August 2019 / Published online: 29 August 2019 
power stations generate huge amount of $F A$, which is a solid waste and a menace for the power plant. FA can be effectively utilized for reclamation of mine spoil [23, 33, 38]. FA has silt sized particles which improves soil pore structure, aeration, decreases bulk density and improves the overall soil physical quality. The improvement in the physical conditions of the soils further helps in inhabitation and growth of soil micro- and macro-organisms. The presence of some of the essential plant nutrients in FA like $\mathrm{Ca}, \mathrm{Mg}, \mathrm{Na}, \mathrm{S}, \mathrm{Fe}, \mathrm{Cu}, \mathrm{Mn}, \mathrm{Zn}$, etc., supports plant growth and increases biomass yield. FA has been found to be very effective for reclamation when it is used with other organic amendments like animal manure, sewage sludge, biochar, sugar industry waste, etc. [37, 39]. Co-application of FA with these amendments has many advantages like decrease in bioavailability of toxic metals, $\mathrm{pH}$ buffering, increase in organic matter, nutrient availability, microbial activity, and overall improvement in soil quality. Biochar is also used for remediation of mine spoil. Application of biochar to mine spoil increases the carbon content in the mine spoil. The increase in carbon content promotes retention of plant nutrients, stimulates microbial growth, and initiates cycling of plant nutrient in the mine spoil, and sequesters heavy metals. Biochar improves physical quality of the mine spoils which in turn helps in proliferation of plant roots. The porous nature of biochar and its high surface area provides a suitable habitat for microbes. Biochar increased the shoot biomass and generally reduced the concentrations of toxic metals in plant species when grown for phytostabilization of mining wastes [7].

Litter fall is the major source of organic matter in the mine spoil. The rate of decomposition of the litter depends on the nature of the litter, moisture, temperature, and microbial communities. In a reclaimed mine spoil, decomposition rate was faster for the $\mathrm{N}$-fixing litter Medicago sativa and dicotyledonous non- $\mathrm{N}$-fixing litter Cirsium arvense (half life of 0.9 years) and was the slowest for the Calamagrostis epigejos grass (half life of 2.6 years) [40]. The highest carbon stock was found in mine spoil treated with sewage sludge ( $33 \mathrm{t} / \mathrm{ha}$ ) and compost ( $45 \mathrm{t} /$ ha) stabilized by lake chalk [37]. Co-application of FA with organic amendments like biochar would enhance carbon storage in mine spoil and supply essential nutrients for plant growth. Artificial soils formed by mixing organic furfural residue and FA could be used for reclamation of mine spoil [15]. FA decreased soil respiration [9]. FA has been reported to increase humification process of soil carbon [6]. Some of the FA properties like, micro pores, alkaline $\mathrm{pH}$, and presence of reactive oxides may be responsible for carbon stabilization in soil $[5,28]$. Amendments of poor structured soils with micro- and mesoporous materials like FA will reduce soil organic carbon turnover and increase its residence time [21]. Different mechanisms of protection of soil C mineralization are physical protection of soil carbon against microbial degradation, conversion of labile carbon to non-labile carbon, and suppression of microbial activity due to adverse chemical environment created by FA.

FA has greater potential for use in the reclamation of mine spoil. As FA is devoid of organic carbon, FA has to be applied along with organic manures or biosolids. The role of FA on organic carbon mineralization in mine spoil is not fully understood. Thus, this study is aimed to assess the carbon mineralization of organic manures and biochar applied to FA-amended mine spoil.

\section{Materials and methods}

\subsection{Organic manure, biochar, fly ash, and mine spoil}

Fresh mine spoil (MS) was collected from Vishwakarma opencast projects (N23 $46^{\prime}$, E86 $24^{\circ}$ ), Jharia Coalfields (JCF), Dhanbad, India, for the carbon mineralization experiments. FA sample was collected from a captive power plant located in Dhanbad, India. Organic amendment materials like plant litter $(\mathrm{PL})$, chicken litter $(\mathrm{CL})$, farmyard manure (FYM), and biochar (BC) were also used. FYM and CL were collected from a nearby cattle and poultry farm, respectively. PL comprising of dried leaves and twigs of Cassia siamea (Leguminosae) was added as an amendment. BC was prepared from yard waste consisting of mainly tree litter. Known quantity of air-dried yard waste was taken in stainless steel container with perforated lid, and heated in muffle furnace at $400{ }^{\circ} \mathrm{C}$ for $60 \mathrm{~min}$. After carbonization, the biochar was milled to a homogenous fine powder and passed through 40-mesh sieve and stored for future use in air-tight containers.

\subsection{Sample analysis}

Mine spoil, FA samples and other amendments were airdried and ground to pass through a 2-mm sieve. The $\mathrm{pH}$ and electrical conductivity $(E C)$ of the samples were measured at 1:10 (w/v) soil to water ratio suspension using a calibrated $\mathrm{pH}$ meter and a conductivity meter, respectively. For elemental analysis, a subsample of all the materials was oven-dried, milled to a homogenous fine powder (RM200; Retsch, Castleford, UK), passed through 100-mesh sieve, and stored in air-tight containers. The elemental composition $(\mathrm{C}, \mathrm{H}, \mathrm{N}, \mathrm{S})$ of the samples was determined using a CHNS elemental analyzer (Vario MACRO cube, Elementar Germany). Ash content was determined by heating the samples in a muffle furnace at $750^{\circ} \mathrm{C}$ for $6 \mathrm{~h}$ (ASTM D-1762-84). For FTIR analysis, oven-dried samples were ground to powder, mixed with $\operatorname{KBr}(1: 200 \mathrm{w} / \mathrm{w})$ and pelletized ( $\mathrm{KBr}$ Press Model M-15). The FTIR spectrum of 
the pellets was recorded in a FTIR spectrometer (IRAffinity$1 \mathrm{~S}$, Shimadzu, Japan) at a resolution of $4 \mathrm{~cm}^{-1}$. For determination of plant nutrients and trace elements in MS, FA, FYM, CL, PL, and BC samples, ASTM method D6349-13 for determination of major and minor elements was followed. According to this method, samples were placed in muffle furnace and gradually heated for $1 \mathrm{~h}$ till the temperature reaches $500{ }^{\circ} \mathrm{C}$, heating continued for another $1 \mathrm{~h}$ till the temperature reaches $750{ }^{\circ} \mathrm{C}$, then maintained at $750{ }^{\circ} \mathrm{C}$ for $2 \mathrm{~h}$. The crucibles were cooled, and the resultant ash was grinded to pass through 200-mesh sieve. The ashed samples were then reignited at $750{ }^{\circ} \mathrm{C}$ for $1 \mathrm{~h}$ and again cooled. Ashed samples were then digested with $70 / 30 \mathrm{HCl} /$ $\mathrm{HF}$ mixed acid solution and $2.1 \mathrm{ml} \mathrm{HNO}_{3}$ in a microwave digestion system at $130^{\circ} \mathrm{C}$ for $2 \mathrm{~h}$, to which $1.5 \%$ boric acid was then added and continued digestion for another $1 \mathrm{~h}$, following ASTM method D6349-13. The prepared samples were analyzed in ICP-OES (iCAP 6300Duo, Thermo Fisher Scientific, UK).

\subsection{Carbon mineralization experiment}

About $5-10 \mathrm{~cm}$ of FA or soil cover on the top of the mine spoil helps in reclamation and growth of plant species. In view of this, for the carbon mineralization experiment, we have decided to add about 25\% FA dose to the minespoil, and a high dose of organic amendments equivalent to $100 \mathrm{t} / \mathrm{ha}$. Twenty grams of MS was added in $100 \mathrm{ml}$ airtight bottles; in half of the bottles, $15 \mathrm{~g} \mathrm{MS}$ and $5 \mathrm{~g} \mathrm{FA}$ mixture were added. To the MS and MS-FA mixtures, organic amendments like $\mathrm{FYM}, \mathrm{CL}, \mathrm{PL}$ or $\mathrm{BC}$ were added at the dosage of $1 \%$. There were 10 treatments with three replications with CRD design. The treatment details are listed below:

1. T1: Control (only MS)

2. T2: MS + FA (25\%)

3. T3: MS + FA (25\%) + FYM (1\%)

4. T4: MS + FYM (1\%)

5. T5: $\mathrm{MS}+\mathrm{FA}(25 \%)+\mathrm{CL}(1 \%)$

6. $\mathrm{T} 6: \mathrm{MS}+\mathrm{CL}(1 \%)$

7. $\mathrm{T} 7 \mathrm{MS}+\mathrm{FA}(25 \%)+\mathrm{PL}(1 \%)$

8. T8: $M S+P L(1 \%)$

9. T9: $M S+F A(25 \%)+B C(1 \%)$

10. $\mathrm{T} 10: \mathrm{MS}+\mathrm{BC}(1 \%)$

The required quantities of air-dried amendments were mixed with MS as per the designated treatments, and the mixtures were taken in $100 \mathrm{ml}$ glass bottle having septum cork for gas sampling at periodical intervals. Appropriate amount of distilled water was added to bring the mine spoil mixtures to $25 \%$ water holding capacity [10]. The set up was kept in an incubator at $28^{\circ} \mathrm{C}$, and from the headspace of the bottles, gas samples were collected at periodical intervals using a $1 \mathrm{ml}$ syringe and the $\mathrm{CO}_{2}$ released was measured using gas chromatograph (Bruker, Scion-456-GC). After each sampling, the glass bottles were opened and allowed to equilibrate with the atmosphere for $1 \mathrm{~h}$ and the bottles were closed. The incubation experiment was continued for 372 days.

We fitted the $\mathrm{C}$ mineralization data in a double exponential model [22] using statistical software Sigma Plot 11. In this equation, there are two $C$ pools, one is comparatively stable with low rate of decomposition and the other pool is labile with higher rate of decomposition. The double exponential equation is given below:

$\mathrm{CO}_{2}-\mathrm{C}=\mathrm{C}_{1}\left(1-\exp ^{-k 1 t}\right)+\mathrm{C}_{2}\left(1-\exp ^{-k 2 t}\right)$

where $\mathrm{CO}_{2}-\mathrm{C}$ is the cumulative $\mathrm{C}$ mineralization, $\mathrm{C}_{1}$ and $\mathrm{C}_{2}$ are the size of the stable and labile $C$ pools, respectively, $k 1$ and $k 2$ are their corresponding $\mathrm{CO}_{2}$ emission rates, and $t$ is time.

At the end of the experiment, the soil samples were homogenized, sieved ( $2 \mathrm{~mm}$ size) and stored at $4{ }^{\circ} \mathrm{C}$ till the analysis of soil biological properties. Microbial biomass carbon (MBC) was estimated by chloroform fumigation and extraction method [46]. Dissolved organic carbon (DOC) was calculated from the carbon content in $\mathrm{K}_{2} \mathrm{SO}_{4}$ extracts of non-fumigated soils. Glucose nutrient-induced respiration method was followed for determination of substrate-induced respiration (SIR) [20]. All the soil parameters were analyzed in triplicate, and the mean values are presented on a dry weight basis.

\subsection{Statistical analysis}

One-way analysis of variance was carried out to compare the treatment means. Differences between individual means were evaluated using Duncan's multiple range tests at $P<0.05$. All statistical analyses were done using SYSTAT- 12 .

\section{Results and discussion}

\subsection{Characteristics of mine spoil and amendments}

Basic properties of the MS, FA and amendments added ( $F Y M, C L, P L, B C)$, are given in Table 1. $\mathrm{pH}$ was found to be alkaline in all the amendments. Major plant nutrients $(\mathrm{N}$, $\mathrm{P}, \mathrm{K}, \mathrm{Ca}, \mathrm{Mg}, \mathrm{S}$ ) were the highest in chicken litter. $\mathrm{C}$ content was the highest in biochar followed by plant litter, chicken litter, and farmyard manure. 
Table 1 Characterization of the mine spoil, fly ash, Farmyard manure, chicken litter, plant litter, and biochar (mean $\pm s t a n d a r d ~ d e v i a t i o n, ~ n$, number of replicates $=3$ )

\begin{tabular}{|c|c|c|c|c|c|c|}
\hline & Mine spoil & Fly ash & Farmyard manure & Chicken litter & Plant litter & Biochar \\
\hline $\mathrm{pH}$ & $7.13 \pm 0.32$ & $8.66 \pm 0.63$ & $7.79 \pm 0.52$ & $7.67 \pm 0.61$ & $7.47 \pm 0.43$ & $9.77 \pm 0.46$ \\
\hline $\mathrm{EC}(\mathrm{dS} / \mathrm{m})$ & $0.42 \pm 0.03$ & $0.59 \pm 0.02$ & $3.62 \pm 0.03$ & $9.55 \pm 0.03$ & $3.35 \pm 0.04$ & $1.85 \pm 0.03$ \\
\hline Total C (\%) & $2.40 \pm 0.13$ & $13.22 \pm 1.2$ & $17.70 \pm 2.3$ & $28.53 \pm 3.4$ & $45.23 \pm 4.2$ & $58.54 \pm 4.8$ \\
\hline \multicolumn{7}{|c|}{ Plant nutrients (\%) } \\
\hline $\mathrm{N}$ & $0.96 \pm 0.01$ & $0.67 \pm 0.01$ & $1.37 \pm 0.02$ & $2.54 \pm 0.03$ & $1.61 \pm 0.01$ & $1.14 \pm 0.02$ \\
\hline$P$ & $0.052 \pm 0.00$ & $0.529 \pm 0.01$ & $0.72 \pm 0.01$ & $4.23 \pm 0.09$ & $0.04 \pm 0.00$ & $0.28 \pm 0.00$ \\
\hline K & $0.214 \pm 0.0$ & $0.625 \pm 0.01$ & $2.20 \pm 0.01$ & $5.89 \pm 0.08$ & $0.38 \pm 0.02$ & $1.94 \pm 0.35$ \\
\hline $\mathrm{Ca}$ & $1.05 \pm 0.01$ & $1.4 \pm 0.02$ & $1.72 \pm 0.03$ & $5.01 \pm 0.05$ & $1.60 \pm 0.03$ & $5.68 \pm 0.54$ \\
\hline $\mathrm{Mg}$ & $0.079 \pm 0.00$ & $0.044 \pm 0.00$ & $0.78 \pm 0.02$ & $2.14 \pm 0.06$ & $0.27 \pm 0.04$ & $0.79 \pm 0.04$ \\
\hline$S$ & $0.041 \pm 0.00$ & $0.182 \pm 0.02$ & $0.19 \pm 0.05$ & $1.00 \pm 0.29$ & $0.08 \pm 0.00$ & $0.39 \pm 0.03$ \\
\hline \multicolumn{7}{|c|}{ Trace elements (mg/kg) } \\
\hline As & $1.43 \pm 0.02$ & $2.24 \pm 0.03$ & $1.53 \pm 0.03$ & $1.66 \pm 0.02$ & $6.15 \pm 0.04$ & $26.2 \pm 3.02$ \\
\hline $\mathrm{Cd}$ & $0.15 \pm 0.01$ & $1.86 \pm 0.02$ & $1.35 \pm 0.02$ & $1.87 \pm 0.03$ & $0.02 \pm 0.0$ & $0.65 \pm 0.02$ \\
\hline Co & $3.4 \pm 0.03$ & $11.1 \pm 0.08$ & $49.6 \pm 4.7$ & $14.1 \pm 3.1$ & $0.43 \pm 0.01$ & $2.08 \pm 0.07$ \\
\hline $\mathrm{Cr}$ & $12.8 \pm 1.4$ & $39.6 \pm 3.3$ & $128 \pm 5.4$ & $135 \pm 4.6$ & $15.4 \pm 2.1$ & $28.8 \pm 0.67$ \\
\hline $\mathrm{Cu}$ & $13.3 \pm 2.1$ & $33.6 \pm 3.5$ & $4.32 \pm 0.4$ & $2671 \pm 32.2$ & $19.3 \pm 2.4$ & $0.83 \pm 0.09$ \\
\hline $\mathrm{Fe}$ & $9248 \pm 143$ & $17452 \pm 164$ & $33204 \pm 138$ & $18366 \pm 163$ & $738 \pm 51$ & $7851 \pm 356$ \\
\hline $\mathrm{Mn}$ & $171 \pm 7.2$ & $220 \pm 11.4$ & $1297 \pm 32.1$ & $1508 \pm 23.4$ & $99.0 \pm 6.3$ & $321 \pm 24.4$ \\
\hline $\mathrm{Ni}$ & $16.8 \pm 3.2$ & $21 \pm 2.1$ & $208 \pm 14.2$ & $123 \pm 13.1$ & $7.28 \pm 0.92$ & $23.1 \pm 6.21$ \\
\hline $\mathrm{Pb}$ & $3.12 \pm 0.05$ & $4.32 \pm 0.3$ & $10.1 \pm 0.8$ & $18.0 \pm 2.1$ & $27.9 \pm 3.5$ & $8.08 \pm 0.64$ \\
\hline $\mathrm{Zn}$ & $37.5 \pm 2.3$ & $30.6 \pm 4.1$ & $721 \pm 53.2$ & $431 \pm 36.7$ & $100 \pm 12.3$ & $323 \pm 32.1$ \\
\hline
\end{tabular}

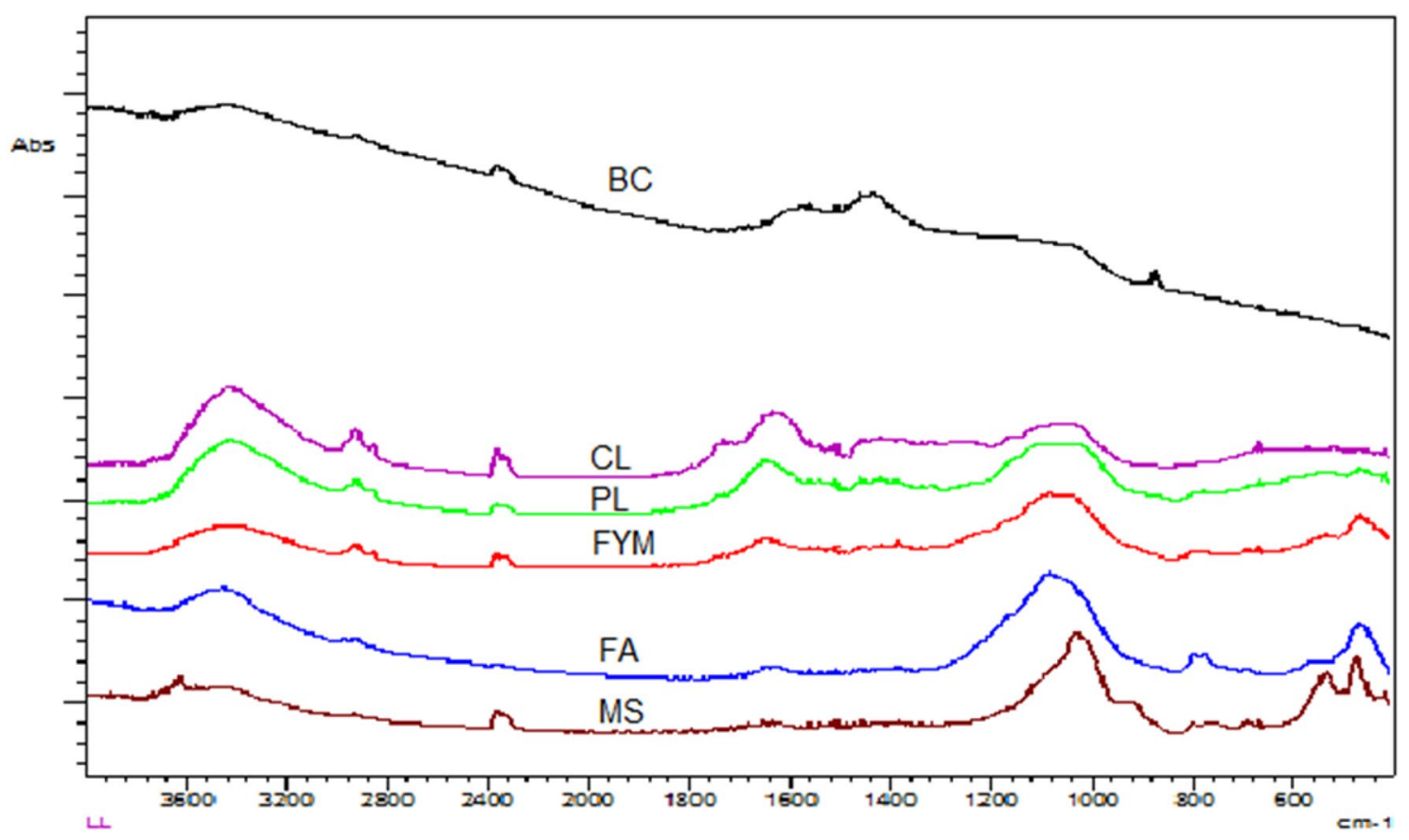

Fig. 1 FTIR spectra of amendments used for carbon mineralization experiment. MS mine spoil, FA fly ash, FYM farmyard manure, PL plant litter, $C L$ chicken litter, $B C$ biochar 


\subsubsection{FTIR analysis}

FTIR analysis (Fig. 1) showed three different groups (1) $\mathrm{MS}$ and $\mathrm{FA} ;(2) \mathrm{FYM}, \mathrm{PL}$, and $\mathrm{CL} ;$ (3) $\mathrm{BC}$. Common spectral signals observed for all the materials are: $3631 \mathrm{~cm}^{-1}, \mathrm{O}-\mathrm{H}$ vibrations of surface hydroxyl group associated with $\mathrm{H}_{2} \mathrm{O}$; $2900 \mathrm{~cm}^{-1}$, symmetric and asymmetric stretching vibrations of aliphatic $\mathrm{C}-\mathrm{H}$ bands. For MS and $\mathrm{FA}$, various mineral oxide peaks were observed (a sharp peak at $1031 \mathrm{~cm}^{-1}$ and a shoulder at $920 \mathrm{~cm}^{-1}$ is associated with $\mathrm{Si}-\mathrm{OH}$ bending, $1083 \mathrm{~cm}^{-1}$ is due to ( $\mathrm{Si}-\mathrm{O}-\mathrm{Si}$ ) asymmetric stretching vibration; $796 \mathrm{~cm}^{-1}$ for $\mathrm{Al} / \mathrm{Si}-\mathrm{O}$ bending, and $472 \mathrm{~cm}^{-1}$ for $\mathrm{Si}-\mathrm{O}-\mathrm{Si}$ bending).In the spectra of biochar, aromatic skeletal vibration or $\mathrm{C}-\mathrm{O}$ stretching vibration $\left(1435 \mathrm{~cm}^{-1}\right)$ [11]; $\mathrm{C}=\mathrm{O}$ in carboxylates, ketones, quinones or $\mathrm{C}=\mathrm{C}$ stretching vibration in aromatic components $\left(1580 \mathrm{~cm}^{-1}\right)$; bending vibrations from carbonates $\left(875 \mathrm{~cm}^{-1}\right.$ and $\left.712 \mathrm{~cm}^{-1}\right)$ were observed. In addition, certain aromatic $\mathrm{C}=\mathrm{C}$ ring stretching bands (around $1600 \mathrm{~cm}^{-1}$ to $1450 \mathrm{~cm}^{-1}$ ) occurred in $B C$ spectra. Other studies also suggest development of fused aromatic structures in BC [11]. During pyrolysis, all the volatiles from the biomass are released and make the residual carbon molecules more aromatic in nature [12]. FYM and $\mathrm{CL}$ showed a broad band around $3430 \mathrm{~cm}^{-1}$ attributed to $\mathrm{O}-\mathrm{H}$ stretching of hydroxyl groups and/or amide and amine $\mathrm{N}-\mathrm{H}$ stretching (Fig. 1). $\mathrm{C}-\mathrm{O}$ stretching of polysaccharides $\left(1082 \mathrm{~cm}^{-1}\right)$ [27] and $\mathrm{C}=\mathrm{O}$ stretching of amide groups in proteins and aromatic $\mathrm{C}=\mathrm{C}$ stretching, amide $\mathrm{C}=\mathrm{O}$ stretching and amide $\mathrm{N}-\mathrm{H}$ bending $\left(1645 \mathrm{~cm}^{-1}\right)$ were observed. Spectra of PL showed the characteristic bands of lignin $\left(1510 \mathrm{~cm}^{-1,} 1738 \mathrm{~cm}^{-1}\right)$ and carbohydrates $(1456$, $1418,1376,1338$ and $1317 \mathrm{~cm}^{-1}$ ) [34].

The above discussion on FTIR results showed that biochar is dominated by aromatic functional groups; FYM and $\mathrm{CL}$ by polysaccharides and amines; PL by lignin and carbohydrates. So, it is evinced that the amendments used for the study have different degrees of carbon lability: FYM, and $C L$ is more labile because of the presence of polysaccharides, and amines; PL is moderately labile due to the presence of lignocellulosic materials; biochar is non-labile as indicated by the aromatic functional groups.

\subsection{Carbon mineralization}

Carbon mineralization experiment was conducted from processed $(<2 \mathrm{~mm})$ soil samples, and there could be limitation that soil preparation might have affected some fraction of the labile pool. The other limitation could be the soil physical conditions in the experiment could be different from the intrinsic field soil environment. However, these standard laboratory incubation protocols were widely used for carbon mineralization studies [16].

Carbon mineralization from the amended mine spoils was faster during the initial 80 to 100 days, and thereafter, it decreased; however, this trend was not observed in control (MS), MS + FA, and BC-amended soils (Fig. 2). The cumulative $\mathrm{CO}_{2}$ emission was lower for the FA-added mine spoil, and among the organic amendments, it was higher for PL (4.42 vs. $5.09 \mathrm{~g} \mathrm{CO}_{2}-\mathrm{C} / \mathrm{kg}$ soil, with and without $\mathrm{FA}$, respectively) and $\mathrm{CL}$ ( 3.75 vs. $4.07 \mathrm{~g} \mathrm{CO}_{2}-\mathrm{C} / \mathrm{kg}$ soil)
Fig. 2 Cumulative $\mathrm{CO}_{2}$ emission from mine spoil (MS) amended with fly ash (FA), farmyard manure (FYM), chicken litter $(\mathrm{CL})$, plant litter $(\mathrm{PL})$ and biochar $(\mathrm{BC})$

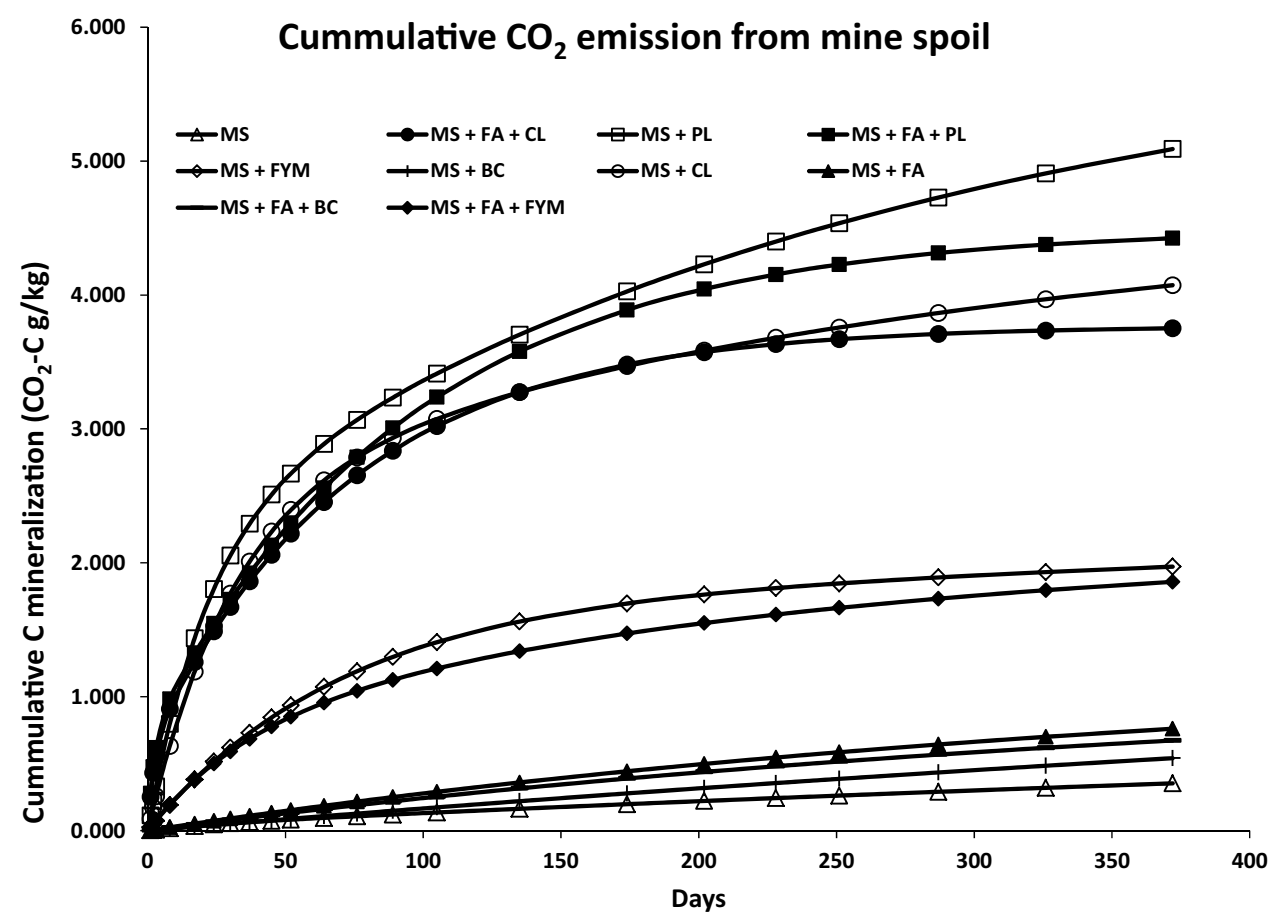

SN Applied Sciences A SPRINGER NATURE journal 
amended soil followed by FYM (1.86 vs. $1.97 \mathrm{~g} \mathrm{CO}_{2}-\mathrm{C} / \mathrm{kg}$ soil). It has been reported that addition of fresh organic matter like plant litter, sewage sludge, etc., would increase the soil microbial respiration and $\mathrm{CO}_{2}$ emission [14]. Addition of fresh organic matter to soil initially underwent a rapid decomposition of the labile organic fraction, followed by decomposition of resistant organic fraction. This sequence of decomposition rate has resulted in an exponential curve which tends to flatten at latter period of incubation [18]. The mineralization rate was the lowest in the unamended mine spoil and biochar-added treatments. This may be due to the presence of coal-based recalcitrant carbon in mine spoil [44]. Higher $\mathrm{CO}_{2}$ emitted in the soils amended with PL and CL compared to those treated with FYM can be directly associated to higher amount of organic matter incorporated with $\mathrm{PL}$ and $\mathrm{CL}$. Though PL and $\mathrm{BC}$ have comparable $\mathrm{C}$ content, more $\mathrm{CO}_{2}$ was emitted per unit of $P L$ than $B C$ which clearly suggests that the organic matter in $\mathrm{PL}$ is less stable. BC carbon is resistant to microbial degradation due to the aromatic structure $[4,42]$.

After 1 year of carbon mineralization experiment, it is observed that FYM, PL, and CL-amended mine spoil reached a stable mineralization rate. Though the $\mathrm{CO}_{2}$ emission rate is slower for $\mathrm{BC}$ and control, a linear pattern was observed even after 1 year of incubation. This could be due to abiotic decomposition of organic carbon in BC [47].

The best-fit parameters of the nonlinear regression analysis of the $\mathrm{CO}_{2}$ emission data using a double decomposition model are given in Table 2. The type of organic amendment significantly affected the size and the mineralization of the labile and stable carbon pool. The carbon pools were larger for PL, followed by $\mathrm{CL}$ and FYM. BC did not follow a double exponential model, the trend is linear, accordingly the size of the labile and stable carbon pools and their mineralization rates were not different. Similar results were reported by [16]. The labile carbon pool is relatively low in FYM-amended soil as we have used composted manure. Composted manure has lower decomposition rate than the fresh litter which is due to the stable fractions of organic $C$ in FYM after composting. The $C$ in FYM is more recalcitrant than the $\mathrm{C}$ in PL or CL. [25] also reported lower $\mathrm{CO}_{2}-\mathrm{C}$ evolution from $\mathrm{FYM}$ than $\mathrm{CL}$.

The mineralization rate constants $(k)$ varied significantly between the treatments (Table 2). Mineralization rate of the labile $\mathrm{C}$ pool was higher in $\mathrm{CL}(0.432)$, followed by $\mathrm{PL}$ (0.419) and FYM (0.028) which suggests the differential C stability of the amendments used. Higher mineralization in $C L$ is due to rapid mineralization of hydrolysable $C$ under aerobic conditions [24]. BC-amended mine spoils and control soil have lower $k$ values $(0.001)$ which indicate the lack of labile organic matter available for microbial mineralization. For the stable carbon pool, also similar trend was observed for the rate constant $(k 2)$, but the differences were narrower.

$\mathrm{CO}_{2}$ emission decreased in the presence of FA. The labile $\mathrm{C}$ pool was significantly lower for FA-added soils. On the contrary, the size of the stable carbon pool was higher in FYM (1.4 vs. $0.6 \mathrm{~g} \mathrm{CO}_{2}-\mathrm{C} / \mathrm{kg}$ soil, with and without FA, respectively) and $\mathrm{CL}$ ( 3.17 vs. $2.20 \mathrm{~g} \mathrm{CO}_{2}-\mathrm{C} / \mathrm{kg}$ soil) in the presence of FA (Table 2). In case of PL, the stable pool was not affected by FA. Earlier studies showed that addition of FA significantly decreased soil C mineralization [36]. The reduction in $\mathrm{C}$ mineralization due to $\mathrm{FA}$ could be due to the extreme $\mathrm{pH}$, the presence of heavy metals, amorphous aluminosilicates and black carbon. FA may form organomineral complexes that are more stable and resistant to microbial decomposition [43]. Kleber [26] reported that
Table 2 Labile and stable $\mathrm{C}$ pool and their decomposition rates ( $k 1$ and $k 2$ ) estimated by a double exponential model

\begin{tabular}{llllll}
\hline Treatments & $\begin{array}{l}\text { Labile pool }\left(C_{1}\right)(\mathrm{g} \\
\left.\mathrm{CO}_{2}-\mathrm{C} / \mathrm{kg} \mathrm{soil}\right)\end{array}$ & $k 1$ & $\begin{array}{l}\text { Stable pool }\left(C_{2}\right)(\mathrm{g} \\
\left.\mathrm{CO}_{2}-\mathrm{C} / \mathrm{kg} \mathrm{soil}\right)\end{array}$ & $k 2$ & $R^{2}$ \\
\hline MS & $1.04^{\mathrm{c}}$ & $0.010^{\mathrm{d}}$ & $0.03^{\mathrm{f}}$ & $0.004^{\mathrm{c}}$ & 0.996 \\
$\mathrm{MS}+\mathrm{FA}$ & $0.624^{\mathrm{de}}$ & $0.002^{\mathrm{e}}$ & $0.636^{\mathrm{de}}$ & $0.002^{\mathrm{cd}}$ & 0.991 \\
$\mathrm{MS}+\mathrm{FA}+\mathrm{FYM}$ & $0.749^{\mathrm{d}}$ & $0.028^{\mathrm{c}}$ & $1.40^{\mathrm{c}}$ & $0.004^{\mathrm{c}}$ & 0.999 \\
$\mathrm{MS}+\mathrm{FYM}$ & $1.71^{\mathrm{b}}$ & $0.010^{\mathrm{d}}$ & $0.60^{\mathrm{e}}$ & $0.001^{\mathrm{d}}$ & 0.995 \\
$\mathrm{MS}+\mathrm{FA}+\mathrm{CL}$ & $0.597^{\mathrm{e}}$ & $0.432^{\mathrm{a}}$ & $3.17^{\mathrm{ab}}$ & $0.014^{\mathrm{a}}$ & 0.995 \\
$\mathrm{MS}+\mathrm{CL}$ & $2.49^{\mathrm{a}}$ & $0.030^{\mathrm{c}}$ & $2.20^{\mathrm{b}}$ & $0.003^{\mathrm{de}}$ & 0.988 \\
$\mathrm{MS}+\mathrm{FA}+\mathrm{PL}$ & $0.701^{\mathrm{d}}$ & $0.419^{\mathrm{a}}$ & $3.80^{\mathrm{a}}$ & $0.010^{\mathrm{b}}$ & 0.995 \\
$\mathrm{MS}+\mathrm{PL}$ & $2.16^{\mathrm{ab}}$ & $0.050^{\mathrm{b}}$ & $3.90^{\mathrm{a}}$ & $0.004^{\mathrm{c}}$ & 0.992 \\
$\mathrm{MS}+\mathrm{FA}+\mathrm{BC}$ & $0.566^{\mathrm{e}}$ & $0.002^{\mathrm{e}}$ & $0.574^{\mathrm{e}}$ & $0.002^{\mathrm{cd}}$ & 0.989 \\
$\mathrm{MS}+\mathrm{BC}$ & $0.873^{\mathrm{cd}}$ & $0.001^{\mathrm{f}}$ & $0.873^{\mathrm{d}}$ & $0.001^{\mathrm{d}}$ & 0.938 \\
\hline
\end{tabular}

$\mathrm{R}^{2}$, coefficient of determination, $\mathrm{k}=$ rate constant (mean with same alphabets are not significant at $P<0.05)$

MS mine spoil, FA fly ash, FYM farmyard manure, $P L$ plant litter, $C L$ chicken litter, $B C$ biochar 

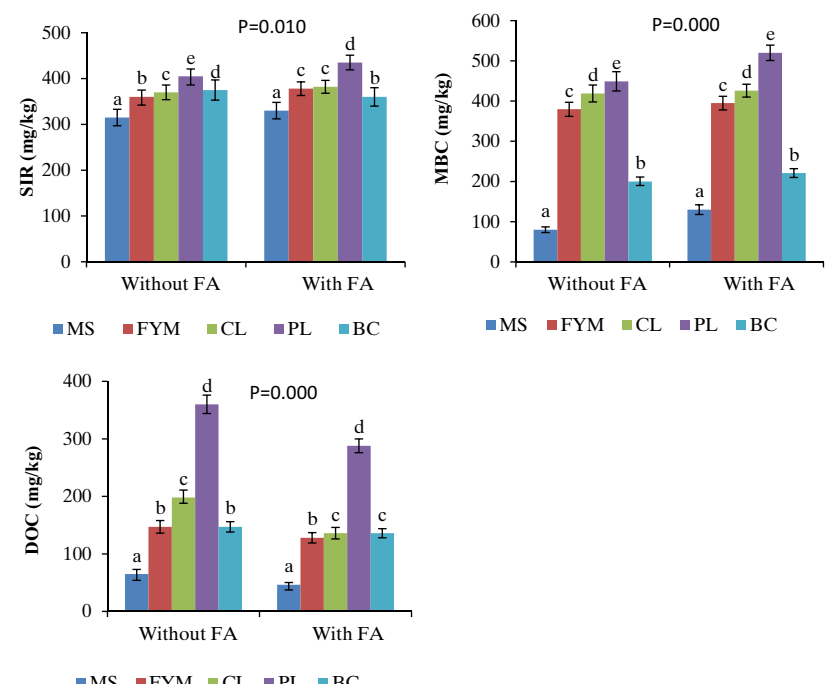

Fig. 3 Effect of fly ash and different amendments on mine spoil dissolved organic $C(D O C)$, microbial biomass $C(M B C)$, and substrateinduced respiration (SIR). MS mine spoil, FA fly ash, FYM farmyard manure, $P L$ plant litter, $C L$ chicken litter, $B C$ biochar, $(n=3$; error bar, standard deviation; mean with same alphabets is not significant at $P<0.05 ; t$ significance between FA treatments is depicted as $P$ values in the graph)

the interaction of FA and soil creates a protective structural network that protects the decomposition of organic carbon. Development of soil micro aggregates upon FA amendment provides physical protection of soil organic matter. Increase in stable carbon pool with FA addition depicts that a fraction of the added carbon is protected by FA depending on the availability of active sites in FA and added organic matter. FA addition to soil improves the storage of soil carbon by stabilization and physical protection of soil carbon [33]. The other possible mechanism for carbon stabilization is FA that catalyzes the conversion of labile and unstable organic $C$ in soil into stable humus [21].

At the end of the $C$ mineralization experiment, the residual soil was homogenized and analyzed for some biological parameters. Substrate-induced respiration (SIR), MBC, and dissolved organic carbon were significantly higher under PL-added mine spoil followed by $C L$ and FYM treatments (Fig. 3). SIR was not affected by FA. However, microbial biomass carbon (MBC) increased significantly with FA (Fig. 3) and dissolved organic carbon decreased. $\mathrm{PL}, \mathrm{CL}$, and FYM increased the soil biological activity probably due to the energy released from the organic matter decomposition [17]. Application of FA-enhanced MBC, probably due to the improvement in soil physical environment and increase in availability of nutrient elements required for the growth of microorganisms [35]. DOC was higher under MS with plant litters, whereas least under
MS with FA (Fig. 3). The decrease in DOC with FA addition (Fig. 3c) is probably due to the sorption of organic carbon on FA. Soil organic carbon decomposition is inhibited by organo-mineral interactions between FA and the organic matter at molecular to millimeter scales [21]. Organic matter stabilization may occur by its sorption on mineral and organic soil surfaces, and deposition in pores and other inaccessible locations where the decomposers and soil enzymes could not attack [28]. Besides carbon stabilization, this organo-mineral interaction improves the mine spoil quality by increasing microbial activity, controlling the availability of metals by binding ions to organic molecules and releasing nutrients that can be utilized by plants [39].

FTIR analysis (Fig. 4) was carried out with the residual soils of the carbon mineralization experiment. Almost similar FTIR pattern was observed for all the amendments. Around $3000-2800 \mathrm{~cm}^{-1}$, the $\mathrm{C}-\mathrm{H}$ aliphatic peaks are prominent for $\mathrm{CL}$ and $\mathrm{FYM}$. Si-O peak obtained at $1100-900 \mathrm{~cm}^{-1}$ was present in all the soils. There is a significant difference in the sharpness of the Si-O peak, especially wherever FA was added the peaks are sharper. However, in BC treated mine spoil, the sharpness of the peak was decreased when FA was added. This is probably due to loss of mineralizable polysaccharide and other carbohydrate-based carbon molecules present in $\mathrm{PL}$ and $\mathrm{CL}$ (Fig. 1). In PL, FYM or CL-added mine spoil the $\mathrm{Si}-\mathrm{O}$ sites of FA are available, but in case of biochar-added soil, the aromatic $\mathrm{C}$ of biochar get adsorbed on the FA surfaces which decreases the sharpness of the $\mathrm{Si}-\mathrm{O}$ peaks. Further studies on the molecular level interaction between FA and organic matter are required for better understanding of the mechanism of carbon stabilization by FA.

\section{Conclusion}

Cumulative $\mathrm{CO}_{2}$ emission was higher for plant litter (4.42 vs. $5.09 \mathrm{~g} \mathrm{CO}_{2}-\mathrm{C} / \mathrm{kg}$ soil, with and without $\mathrm{FA}$, respectively) and chicken litter ( 3.75 vs. $4.07 \mathrm{~g} \mathrm{CO}_{2}-\mathrm{C} / \mathrm{kg}$ soil) amended soil followed by farm yard manure (1.86 vs. $1.97 \mathrm{~g} \mathrm{CO}_{2}-\mathrm{C} /$ $\mathrm{kg}$ soil). The carbon pools were larger for plant litter, followed by chicken litter and farm yard manure-added mine spoil. Carbon mineralization rate was higher in chicken litter, followed by plant litter and farm yard manure. The labile $\mathrm{C}$ pool was significantly lower for FA-added soils. On the contrary, the size of the stable carbon pool was higher in FA-added soils: farm yard manure $\left(1.4\right.$ vs. $0.6 \mathrm{~g} \mathrm{CO}_{2}-\mathrm{C} / \mathrm{kg}$ soil, with and without $F A$, respectively), chicken litter (3.17 vs. $2.20 \mathrm{~g} \mathrm{CO}_{2}-\mathrm{C} / \mathrm{kg}$ soil, with and without $\mathrm{FA}$, respectively). Substrate-induced respiration, microbial biomass carbon, 
(a) Plant litter

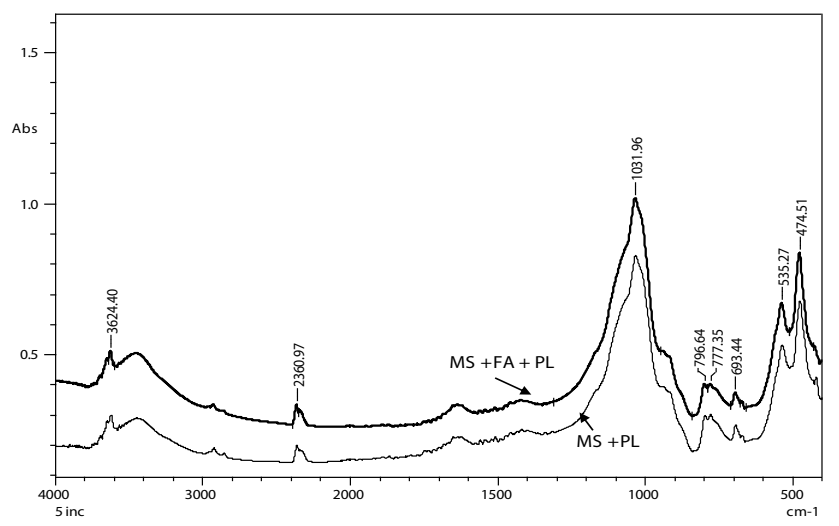

(c) Chicken litter

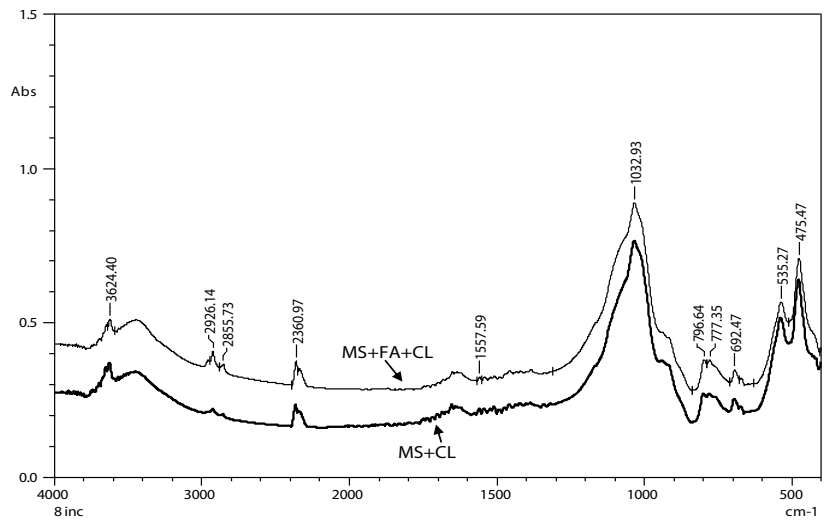

(b) Farm yard manure

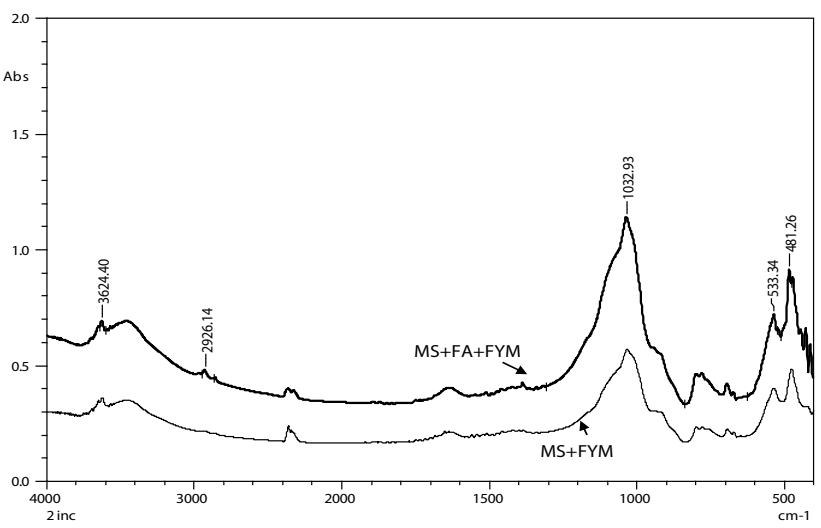

(d) Biochar

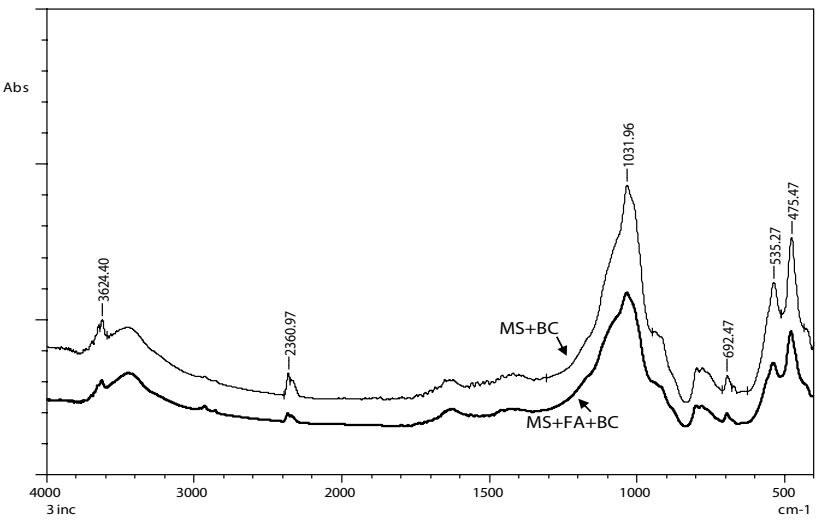

Fig. 4 FTIR spectra of mine spoil amended with manures, biochar, and fly ash. MS mine spoil, FA fly ash, FYM farmyard manure, PL plant litter, $C L$ chicken litter, $B C$ biochar

and dissolved organic carbon were significantly higher under plant litter-added mine spoil followed by chicken litter and farm yard manure treatments. FA increased microbial biomass carbon but decreased dissolved organic carbon. Overall, FA decreased the cumulative $\mathrm{CO}_{2}$ emission from mine spoil.

Acknowledgements Sincere thanks to the Director of the CSIR-Central Institute of Mining and Fuel Research, Dhanbad, India, for supporting this work. The financial support by the Science and Engineering Research Board, Ministry of Science and Technology, Government of India (Fast Track Scheme for Young Scientist, SR/FTP/ES-48/2013) is greatly acknowledged.

\section{Compliance with ethical standards}

Conflict of interest On behalf of all authors, the corresponding author states that there is no conflict of interest.

Informed consent Informed Consent obtained from the cattle and poultry manure supplier for use of the respective litters in this study.

\section{References}

1. Ahirwal J, Kumar A, Petrokovy M, Maiti SK (2018) Reclamation of coal mine spoil and its effect on technosols quality and carbon sequestration: a case study from India. Environ Sci Pollut Res 25(28):27992-28003

2. Ahirwal J, Maiti SK (2017) Assessment of carbon sequestration potential of revegetated coal mine overburden dumps: a chronosequence study from dry tropical climate. J Environ Manag 201:369-377

3. Ahirwal J, Maiti SK (2018) Assessment of soil carbon pool, carbon sequestration and soil $\mathrm{CO}_{2}$ flux in unreclaimed and reclaimed coal mine spoils. Environ Earth Sci 77:9

4. Ameloot N, Sleutel S, Case SDC, Alberti G, McNamara NP, ZavalIoni C, Vervisch B, Vedove Gd, De Neve S (2014) C mineralization and microbial activity in four biochar field experiments several years after incorporation. Soil Biol Biochem 78:195-203. https ://doi.org/10.1016/j.soilbio.2014.08.004

5. Amonette JE, Kim J, Russell CK, Palumbo AV, Daniels WL (2003) Enhancement of soil carbon sequestration by amendment with fly ash. In: Proceedings, International Ash Utilisation Symposium, Center for Applied Energy Research, University of Kentucky, Paper 47

6. Amonette JE, Kim J, Russell CK, Palumbo AV, Daniels WL (2003) Fly ash amendments catalyze soil carbon sequestration. In: Second annual conference on carbon sequestration, pp 5-8 
7. Anawar HM, Akter F, Solaiman ZM, Strezov V (2015) Biochar: an emerging panacea for remediation of soil contaminants from mining, industry and sewage wastes. Pedosphere 25:654-665. https://doi.org/10.1016/S1002-0160(15)30046-1

8. ASTM D6349-13 (2013) Standard test method for determination of major and minor elements in coal, coke, and solid residues from combustion of coal and coke by inductively coupled plasma-atomic emission spectrometry, ASTM International, West Conshohocken, PA. www.astm.org

9. Belyaeva ON, Haynes RJ (2012) Comparison of the effects of conventional organic amendments and biochar on the chemical, physical and microbial properties of coal fly ash as a plant growth medium. Environ Earth Sci 66:1987-1997. https://doi. org/10.1007/s12665-011-1424-y

10. Chen $\mathrm{S}$, Wang $\mathrm{Y}, \mathrm{Hu} \mathrm{Z}$, Gao H (2015) $\mathrm{CO}_{2}$ emissions from a forest soil as influenced by amendments of different crop straws: implications for priming effects. CATENA 131:56-63. https:// doi.org/10.1016/j.catena.2015.03.016

11. Chi J, Liu H (2016) Effects of biochars derived from different pyrolysis temperatures on growth of Vallisneria spiralis and dissipation of polycyclic aromatic hydrocarbons in sediments. Ecol Eng 93:199-206. https://doi.org/10.1016/j.ecole ng.2016.05.036

12. Das O, Bhattacharyya D, Sarmah AK (2016) Sustainable ecocomposites obtained from waste derived biochar: a consideration in performance properties, production costs, and environmental impact. J Clean Prod 129:159-168. https://doi. org/10.1016/j.jclepro.2016.04.088

13. Das R, Maiti SK (2016) Importance of carbon fractionation for the estimation of carbon sequestration in reclaimed coalmine soils-a case study from Jharia Coalfields, Jharkhand, India. Ecol Eng 90:135-140

14. Dick RP (1992) A review: long-term effects of agricultural systems on soil biochemical and microbial parameters. Agr Ecosyst Environ 40:25-36. https://doi.org/10.1016/01678809(92)90081-L

15. Feng Y-J, Li F, Wang X-L, Liu X-M, Zhang L-N (2006) Principal chemical properties of artificial soil composed of fly ash and furfural residue. Pedosphere 16:668-672. https://doi. org/10.1016/S1002-0160(06)60101-X

16. Fernández JM, Nieto MA, López-de-Sá EG, Gascó G, Méndez A, Plaza C (2014) Carbon dioxide emissions from semi-arid soils amended with biochar alone or combined with mineral and organic fertilizers. Sci Total Environ 482-483:1-7. https://doi. org/10.1016/j.scitotenv.2014.02.103

17. Fontaine $S$, Mariotti A, Abbadie $L$ (2003) The priming effect of organic matter: a question of microbial competition? Soil Biol Biochem 35:837-843. https://doi.org/10.1016/S0038 $-0717(03) 00123-8$

18. Hallam MJ, Bartholomew WV (1953) Influence of rate of plant residue addition in accelerating the decomposition of soil organic matter1. Soil Sci Soc Am J 17:365-368. https://doi. org/10.2136/sssaj1953.03615995001700040016x

19. IEO (2016) International Energy Outlook, Report Number: Doe/Eia-0484(2016), EIA, U.S. Energy Information Administration. http://www.eia.gov/forecasts/ieo/coal.cfm

20. Islam KR, Weil RR (2000) Land use effects on soil quality in a tropical forest ecosystem of Bangladesh. Agr Ecosyst Environ 79:9-16. https://doi.org/10.1016/S0167-8809(99)00145-0

21. Jastrow JD, Amonette JE, Bailey VL (2007) Mechanisms controlling soil carbon turnover and their potential application for enhancing carbon sequestration. Clim Change 80:5-23. https ://doi.org/10.1007/s10584-006-9178-3

22. Jenkinson DS (1977) Studies on the decomposition of plant material in soil. v. the effects of plant cover and soil type on the loss of carbon from $14 \mathrm{C}$ labelled ryegrass decomposing under field conditions. J Soil Sci 28:424-434. https://doi. org/10.1111/j.1365-2389.1977.tb02250.x

23. Jia Y, Maurice C, Öhlander B (2014) Effect of the alkaline industrial residues fly ash, green liquor dregs, and lime mud on mine tailings oxidation when used as covering material. Environ Earth Sci 72:319-334. https://doi.org/10.1007/s1266 5-013-2953-3

24. Khalil MI, Hossain MB, Schmidhalter U (2005) Carbon and nitrogen mineralization in different upland soils of the subtropics treated with organic materials. Soil Biol Biochem 37:1507-1518. https://doi.org/10.1016/j.soilbio.2005.01.014

25. Kirchmann $\mathrm{H}$ (1991) Carbon and nitrogen mineralisation of fresh, aerobic and anaerobic animal manures during incubation with soil. Swed J Agric Res 21:165-173

26. Kleber $M(2010)$ What is recalcitrant soil organic matter. Environ Chem 7:320-332. https://doi.org/10.1071/EN10006

27. Lima DLD, Santos SM, Scherer HW, Schneider RJ, Duarte AC, Santos EBH, Esteves VI (2009) Effects of organic and inorganic amendments on soil organic matter properties. Geoderma 150:38-45. https://doi.org/10.1016/j.geoderma.2009.01.009

28. Masto RE, Sengupta T, George J, Ram LC, Sunar KK, Selvi VA, Sinha AK (2014) The impact of fly ash amendment on soil carbon. Energy Sources Part A Recovery Util Environ Eff 36:554562. https://doi.org/10.1080/15567036.2010.544004

29. Mishra UC (2004) Environmental impact of coal industry and thermal power plants in India. J Environ Radioact 72(1-2):35-40

30. Mukhopadhyay S, Masto RE (2016) Carbon storage in coal mine spoil by Dalbergia sissoo Roxb. Geoderma 284:204-213. https:// doi.org/10.1016/j.geoderma.2016.09.004

31. Mukhopadhyay S, Masto RE, Cerdà A, Ram LC (2016) Rhizosphere soil indicators for carbon sequestration in a reclaimed coal mine spoil. CATENA 141:100-108. https://doi.org/10.1016/j. catena.2016.02.023

32. Munawer ME (2018) Human health and environmental impacts of coal combustion and post-combustion wastes. J Sustain Min 17:87-96

33. Palumbo AV, McCarthy JF, Amonette JE, Fisher LS, Wullschleger SD, Daniels WL (2004) Prospects for enhancing carbon sequestration and reclamation of degraded lands with fossil-fuel combustion by-products. Adv Environ Res 8:425-438. https://doi. org/10.1016/S1093-0191(02)00124-7

34. Pandey KK (1999) A study of chemical structure of soft and hardwood and wood polymers by FTIR spectroscopy. J Appl Polym Sci 71:1969-1975. https://doi.org/10.1002/(sici)10974628(19990321)71:12\%3c1969:aid-app6\%3e3.0.co;2-d

35. Parab N, Sinha S, Mishra S (2015) Coal fly ash amendment in acidic field: effect on soil microbial activity and onion yield. Appl Soil Ecol 96:211-216. https://doi.org/10.1016/j.apsoi I.2015.08.007

36. Pichtel JR, Hayes JM (1990) Influence of fly ash on soil microbial activity and populations. J Environ Qual 19:593-597. https://doi. org/10.2134/jeq1990.00472425001900030039x

37. Placek-Lapaj A, Grobelak A, Fijalkowski K, Singh BR, Almås ÅR, Kacprzak M (2019) Post-mining soil as carbon storehouse under polish conditions. J Environ Manag 238:307-314. https://doi. org/10.1016/j.jenvman.2019.03.005

38. Ram LC, Masto RE (2010) An appraisal of the potential use of fly ash for reclaiming coal mine spoil. J Environ Manag 91:603-617. https://doi.org/10.1016/j.jenvman.2009.10.004

39. Ram LC, Masto RE (2014) Fly ash for soil amelioration: a review on the influence of ash blending with inorganic and organic amendments. Earth Sci Rev 128:52-74. https://doi.org/10.1016/j. earscirev.2013.10.003

40. Rawlik M, Kasprowicz M, Jagodziński AM, Rawlik K, Kaźmierowski C (2019) Slope exposure and forest stand type as crucial 
factors determining the decomposition rate of herbaceous litter on a reclaimed spoil heap. CATENA 175:219-227. https://doi. org/10.1016/j.catena.2018.12.008

41. Roy M, Roychowdhury R, Mukherjee P (2018) Remediation of fly ash dumpsites through bioenergy crop plantation and generation: a review. Pedosphere 28:561-580. https://doi.org/10.1016/ S1002-0160\%5b18\%5d60033-5

42. Smith JL, Collins HP, Bailey VL (2010) The effect of young biochar on soil respiration. Soil Biol Biochem 42:2345-2347. https://doi. org/10.1016/j.soilbio.2010.09.013

43. Ukwattage NL, Ranjith PG, Bouazza M (2013) The use of coal combustion fly ash as a soil amendment in agricultural lands (with comments on its potential to improve food security and sequester carbon). Fuel 109:400-408. https://doi.org/10.1016/j. fuel.2013.02.016

44. Ussiri DAN, Jacinthe P-A, Lal R (2014) Methods for determination of coal carbon in reclaimed minesoils: a review. Geoderma 214215:155-167. https://doi.org/10.1016/j.geoderma.2013.09.015
45. Ussiri DAN, Lal R (2005) Carbon sequestration in reclaimed minesoils. Crit Rev Plant Sci 24:151-165. https://doi. org/10.1080/07352680591002147

46. Vance ED, Brookes PC, Jenkinson DS (1987) An extraction method for measuring soil microbial biomass $C$. Soil Biol Biochem 19:703-707. https://doi.org/10.1016/0038-0717(87)90052 $-6$

47. Zimmerman AR (2010) Abiotic and microbial oxidation of laboratory-produced black carbon (biochar). Environ Sci Technol 44:1295-1301. https://doi.org/10.1021/es903140c

Publisher's Note Springer Nature remains neutral with regard to jurisdictional claims in published maps and institutional affiliations. 